\title{
The Relationship Between Perception About Personal Protective Usage and The Incidence of Dermatitis in Tanning Industrial Workers Sukaregang Garut
}

\author{
Umar Sumarna*, Witdiawati Witdiawati and Iwan Suhendar \\ Faculty of Nursing, Universitas Padjadjaran, Bandung Indonesia \\ *Correspondence: sumarna111058@gmail.com \\ Type of the Paper (Article)
}

Received: February 1, 2019; Accepted: May 15, 2019; Published: May 31, 2019

https://doi.org/10.29253/achnr.2019.1116

\begin{abstract}
Background: Personal protective equipment is required for workers with potential hazards. The potential hazard is found in the Tanneries Industry Sukaregang Garut because this industry uses a lot of materials that are harmful to health. However, since most workers have a negative perception of the use of personal protective equipment, the impact is that the workers have many health problems, including the incidence of occupational dermatitis which became the focus of this study. Objective: This study aims to determine the relationship between perceptions about the use of personal protective equipment with the incidence of dermatitis on the industrial workers Tanning of Sukaregang Garut. Methods: This study used a cross-sectional design with 139 workers as samples. The data were analyzed using the Chi-Square test. Results: The results showed a significant relationship between the two variables with a p-value of 0.014 and Odds Ratio of 2.517. Conclusions: It can be concluded that the negative perceptions on the use of personal protective equipment would increase the risk of dermatitis cases in the work. The author's recommended solution is the health workers should counsel the workers continuously on the importance of using personal protective equipment in the workplace so that eventually all workers have positive perceptions.
\end{abstract}

Keyword: occupational dermatitis, personal protective equipment, tanneries industry

\section{Introduction}

Personal Protective Equipment (PPE) is a tool or equipment required to protect and maintain safety while performing their work that has potential hazards and risks to the workers. Hughes (2014) defines that PPE is a set of tools used by labour to protect some or all of its body from potential hazards or workplace accidents. While the risks above mentioned above are quite diverse, as mentioned by Pickett (2009), that work-related risks can be viewed as injury, illness, and death from injury, as well as workrelated diseases. Also, Meyer (2012), mentioned various occupational diseases such as pneumoconiosis, occupational dermatitis, chemical poisoning, psychological disorders due to work in every workforce. Pickett and Meyer stated the importance of PPE to protect the workers from the potential hazard caused by their work.

One of the industries that have many workers and many potential hazards is the leather tanning industry. The potential hazard which posed by the leather tanning industry is very high because this 
industry is an industry that processes raw materials into finished materials, which in its processing contains many harmful chemicals such as chromium, sodium disulfide, sulfuric acid, formic acid, and many others. Besides that, many allergen ingredients from the removed part of the leather such as hair, feathers, proteins and fats that can cause skin allergies and the waste cause a foul odor (Covington, 2011).

Leather tannery industry in West Java has been known for a long time that has been established since 1920 (District Health Office Garut, 2012), which is the Tanneries Industry of Sukaregang Garut. Like other tannery industries, the industry produces waste that is polluting the environment highly and threatens the health of the surrounding community. Especially for the industrial workers who contact with hazardous industrial materials at any time.

In the preliminary survey, the authors found that many health problems were complained by workers in the Tanneries Industry of Sukaregang Garut were itchy on the skin. According to a local doctor who diagnosed the illness of workers, the workers suffered from dermatitis. Industri Tanneries Sukaregang Garut is located in the work area of the Pasundan Garut Health Center. Based on data from the Pasundan Garut Health Center, dermatitis ranks 5th out of the top 10 diseases in 2015 and ranks 6th in 2016 and 2017.

The danger may be avoided or minimized by the discipline of using the PPE regularly. The industrial worker chairman has also tried to provide the PPE, consists of helmets to protect the head, masks to protect the respiratory tract, apron to protect the body, gloves to protect the hands and boots to protect the feet. Provision of PPE which implemented by company's chairman refers to the Regulation of the Minister of Manpower and Transmigration of RI no Per 08 / MEN / VII / 2010 which required the workers to use PPE while working in the places with potential hazards and accidents (Collins, 2001).

Despite the supporting factors on the use of PPE in the workplace, in the realities, often the workers ignore the use of the tool for various reasons. According to Hayden (2013), a person's behavior is related to perception. So the behavior of the workers about the use of PPE positively has related to the perception of the workers themselves against PPE.

Based on the background, it is necessary to examine the relationship between perception about personal protective usage and the incidence of dermatitis cases. So the purpose of this study is to know whether there is a relationship between perceptions of the workers with dermatitis cases in the Tanneries Industry of Sukaregang Garut.

\section{Methods}

This research was conducted using Cross-sectional design, through the analytical method to analyze the correlation between perception of PPE usage as the independent variable and the incidence of occupational dermatitis as the dependent variable.

The population in this research are all leather tanning workers in the leather industry of Sukaregang Garut with inclusion criteria of workers who have worked in the leather industry for at least five years. The total population was 850 people, then calculated using the formula by Isaac and Michael in Hasyim (2010) as follows :

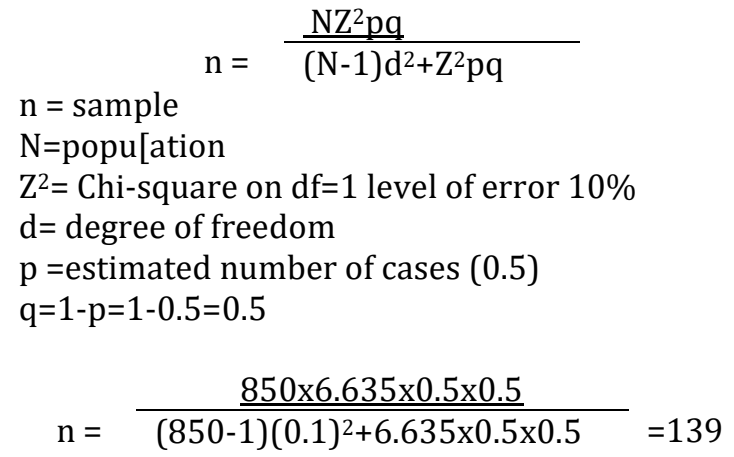

So the sample was taken equal to 139 people.

Test the validity of the questionnaire conducted on 15 workers in the leather tanning industry in Suci Village Garut using Pearson Product Moment Correlation.

$$
r=\frac{\underline{N}\left(\sum X Y\right)-\left(\sum X \sum Y\right)}{\sqrt{\left\{N \sum X^{2}-(X)^{2}\right\}\left\{\sum Y^{2}-\sum(Y)^{2}\right\}}}
$$


In this case, $r$ table for 20 questions at df-2 with significant level 0.05 is 0.514 (Grag, 2012). The results of the validity test show the largest $r=0.746$ and the smallest $r=0.544$. So all questions are declared valid, because of $0.544>0.514$. Reliability test is done by getting Cronbach's $\alpha=0.935$, which proves that all questions are declared reliable because of $0.935>0.514$.

The data were collected through a questionnaire that contains questions about the characteristics of respondents, the perception of the leather industry workers about PPE, and the incidence of occupational dermatitis.

The research instrument consisted of :

1. Characteristics of respondents in a short form consisting of age, gender, education, work experience, working hours in a day.

2. Employee perceptions of PPE usage as measured by a Likert scale with alternative answers

- Very agree given score 4

- Agree given score 3

- Disagree given score 2

- Very disagree given score 1

Then each sheet of respondents' answers are processed to be given categories with two possible outcomes (Azwar 2010) as follows:

a. Positive Perceptions (+) when the respondent value> median value

b. Negative Perceptions ( - ) when the respondent value $<$ median value

3. The case of occupational dermatitis (dependent variable) with two alternative answers: yes or not The analysis test used is the Chi-Square test $2 \times 2$.

\section{Results}

Table 1 showed that the most age group is $40-49$ years old group $(33,09 \%)$, the number of males is more than female who is $62.59 \%$, education of (58,99\%), most of the work experience in the group of 15 19 years $(46.04 \%)$ and the work duration in a day is at most 8 hours, which is $91.37 \%$.

The result of univariate analysis of perception on the PPE usage is depicted in table 2 which showed negative perception more than positive perception, which is $70.50 \%$. The univariate analysis of dermatitis cases in Table 3 depicts that the number of workers exposed to dermatitis was more than those not exposed, that is $59.71 \%$.

Table 1. Characteristics of Respondents

\begin{tabular}{llcc}
\hline \multicolumn{1}{c}{ Characteristic } & Frequency & Percentage \\
\hline Age : & 20-29 years & 28 & \\
30-39 years & 41 & 20.14 \\
40-49 years & 46 & 29.50 \\
50-60 years & 24 & 17.27 \\
Gender : & & \\
Male & 52 & 37.41 \\
Female & 87 & 62.59 \\
Education : & & \\
Elementary School & 82 & 58,99 \\
Yunior High School & 34 & 24.46 \\
Senior High School & 23 & 16.55 \\
Work Experience : & & 7.20 \\
5-9 years & 10 & 25.90 \\
10-14 years & 36 & 46.04 \\
15-19 years & 64 & 20.86 \\
$\geq 20$ years & 29 & \\
< 8 hours & & 91.37 \\
$>$ 8 hours & 127 & 8.63 \\
\hline
\end{tabular}


Table 2. Respondent's Perception of PPE usage

\begin{tabular}{lccc}
\hline & Perception of PPE usage & Frequency & Percentase \\
\hline Negative & & 98 & 70.50 \\
Positive & & 41 & 29.50 \\
\hline & Jumlah & 139 & 100 \\
\hline
\end{tabular}

Table 3. Dermatitis Case of Respondent

\begin{tabular}{ccc}
\hline \multicolumn{1}{c}{ Dermatitis Case } & Frequency & Percentage \\
\hline Dermatitis Exposed & 83 & 59.71 \\
Not Dermatitis Exposed & 56 & 40.29 \\
\hline Jumlah & 139 & 100 \\
\hline
\end{tabular}

Table 4. Relationship between Perception of PPE usage against Dermatitis Case

\begin{tabular}{ccccccccc}
\hline Perception of & \multicolumn{9}{c}{ Dermatitis Case } & OR & pValue \\
\cline { 2 - 7 } \multicolumn{1}{c}{ PPE usage } & Yes & $\%$ & No & $\%$ & Total & $\%$ & & \\
\hline Negative & 65 & 66.33 & 33 & 33.67 & 98 & 100 & 2.517 & 0.014 \\
Positive & 18 & 43.90 & 23 & 56.10 & 41 & 100 & & \\
\hline \multicolumn{1}{c}{ Total } & 83 & 59.71 & 56 & 40.29 & 139 & 100 & & \\
\hline
\end{tabular}

After testing the relationship using a chi-square test that is depicted in table 4 , the p-value was 0.014. According to Garg (2012), when $\mathrm{p}$-value $<0.05$, analysis test results stated that $\mathrm{H}_{0}$ was rejected, it means that there is a significant relationship between the worker's perception of PPE usage to the incidence of occupational dermatitis with the value of Odd Ratio (OR) is 2.517. According to Rookes et al. (2000), it means that the workers who have negative perceptions were risked 2.517 times to get dermatitis than the workers who have a positive perception.

\section{Discussion}

The results showed most of the workers (59.71\%) had a negative perception. They were thinking that PPE usage did not give many benefits in maintaining health. The cause of this situation is probably due to the cultural or hereditary habits related to the industry that has been established a long time, and long work experience of the workers, also supported by low education level which leads to wrong thinking patterns and difficult to accept innovation.

According to Rookes et al. (2010), negative perceptions will have an impact on negative behavior as well. In this study, the workers often ignore the use of PPE in work. Also, they did not feel the impact of negative and behavior perceptions directly. The consequences of such behavior are more exposed to industrial chemicals that they lead to the greater risk to expose of dermatitis (Luan et al. 2017).

Rookes et al. (2010) stated that the negative perception is the perception or view of an object that refers to the circumstances in which the subject which percepts tend to reject the object because it does not suit his personality. So, in this case, the workers personally refuse the use of PPE, because the workers personally have been influenced by the work environment.

Another factor that affects one's perception is the psychological factor as revealed by Grondin (2015), namely the availability of previous information, needs, past experiences, emotions, impressions, and context. If these negative perceptions continue to develop, then according to Hayden (2012) will be manifested in the form of behavior that endangers his health, because the perception is also part of the behavior, that is passive behavior.

The government has made the Law no. 1 of 1970 on the Work Safety of Chapter III Article 12 that the workforce has the right and the obligation to use PPE on the work. However, the law has not been 
fully implemented in the company. The results showed that most $(59.71 \%)$ of the workers were diagnosed with dermatitis. This condition might be caused by the behavior of workers who do not support health and the poor environmental health of workers.

According to H.L.Bloom in Notoatmodjo (2010), one's health is influenced by four factors, i.e., behavior (35\%), environment (40\%), health service $(20 \%)$, and genetic (5\%). This study support this theory that the factors of behavioral and environmental health are more dominant than the other two factors.

While when we review to dermatitis that occurs in the laborer of the Tanning Leather Industry of Sukaregang Garut, it appears that the work environment in this industrial environment uses a lot of hazardous chemicals that often make contact with the worker's skin. According to Rudikoff et al. (2014), dermatitis consists of endogenous and exogenous types. The working environment in the tanneries industry that causes dermatitis is outside the worker's body. So dermatitis that suffered many workers is the exogenous type, that is contact dermatitis. Such contact dermatitis has suffered the workers due to their work, then according to Rycroft et al. (2000) can be classified as Occupational Dermatitis Contact.

In spite of the work environment that supports the occurrence of dermatitis, the behavior of the workers is less supporting adapt to the high-risk environment. The government has required workers to use PPE as a way to reduce the incidence of dermatitis and other health problems in the workplace.

The tannery industry is an industry that is always in the environment with harmful chemicals. These materials are the main ingredients in the process of work. Therefore, to eliminate such materials is an impossible thing. So the solution that can be done by health workers to overcome this problem mainly directs the behavior of workers to always pay attention to their hygiene and the use of PPE when they are working.

In this case, the work environment can be improved as clean and healthy as possible without eliminating the chemicals used in the tanning process. The health worker or nurse is also responsible for facilitating the worker at the nearest health facility if the worker and their family need medical services.

The results showed that there is a significant correlation between perception of industrial workers of Sukaregang Garut Tanneries on the use of PPE with the incidence of dermatitis with p-value $=0.014$ and Odd Ratio $(\mathrm{OR})=2,517$ which means the workers who have negative perceptions have a greater possibility for the occurrence of dermatitis.

Based on the above, it is clear that negative perceptions are closely related to the incidence of dermatitis. This fact may cause a negative perception which is manifested in the form of workers' behavior. Behavior does not use PPE is high risk for the occurrence of dermatitis. When many workers suffered from dermatitis, the morbidity rate of dermatitis becomes high.

This situation can be detrimental to both the workers themselves and the industry. For the workers will lead to high budget for treatment, while the industry will lead to high absenteeism, ultimately lowering productivity. A study by Edgar (2009) showed that there is a significant effect on safety and health work on work productivity. In addition to adverse health impact, this also impacts on economic losses.

\section{Conclusion}

Most of the workers in the Tanneries Industry of Garut had a negative perception of the use of PPE in the workplace, and most of the workers were diagnosed with dermatitis. There was a significant relationship between the perception of the use of PPE and the incidence of dermatitis. Thus it can be concluded that cases of dermatitis suffered by the workers most likely to be the impact of negative perceptions on the use of PPE.

Based on the results above, it suggested improving the workers' perceptions of the benefits of using PPE through continuously health education and where necessary by demonstration methods so that they are fully aware of the dangers that threaten every worker employed in the leather tanning industry.

\section{References}

Azwar, S. (2010). Persepsi Manusia, Teori dan Pengukurannya. Pustaka Pelajar. Collins, LR., Schneid, TD (2001). Physical Hazard of The Working Place. Ed 1st. CRC Press. 
Covington, Anthony D. (2011). Tanning Chemistry The Science of Leather. Ed 1st. Royal Society of Chemistry (RSC) Publishing.

Dinas Kesehatan Kabupaten Garut. (2012). Profil Kesehatan Kabupaten Garut Tahun 2012.

Edgar, Christopher, R. (2002). Inner Productivity: A Mindful Path to Efficiency and Enjoyment in Your Work. Cruvado Press.

Frosch, Peter J., Menne T., Lepoittein, JP. (2005). Contact Dermatitis. Ed 2nd. Springer-Verlag Berlin Heidelberg

Garg, Gaurav., Kothary, CR. (2012). Research Methodology, Methods, and Techniques. Ed 2nd. New Age International Publisher.

Grondin. (2016). Psychology of Perception. Springer International Publishing.

Hasyim, Y. (2010). Determining Sufficiency Sample Size in Management Survey Research Activities. International Journal of Organization Entrepreneurship Development Vol 6 (1) pp: 119-130

Hayden, J. (2013). Introduction to Health Behaviour Theory. Ed 1st. Jones \& Barlett Learning.

Hughes, P., Ferret, E. (2014). Introduction to Health and Safety at Work. Ed 5th. Routledge.

Luan, M., Fan, LM., Xie, H., Li, YM. (2017). Comparison of A New Sensitive Skin Questionnaire and Bauman's Sensitive Skin Questionnaire in Chengdu. Journal of Dermatitis 2:108.

Meyer, E. (2015). Chemistry of Hazardous Material. Ed 5th. Pearson.

Notoatmodjo, S. (2010). Ilmu Perilaku Kesehatan. Rineka Cipta.

Pickett, G., Harlon (2009), Public Health Administration and Practice. Ed 7th. Mosby College. Publishing St Louis.

Rookes, P, Wilson, J (2000). Perception: Theory, Development, and Organization. Ed 1st. Routledge.

Rudikoff, D., Cohen, SR., Scheinfield, N., (2014). Atopic Dermatitis and Eczematous Disorders. Ed 1st. CRC Press.

Rycroft, RJG., Menne, T., Frosch, PJ., Lepoittevin, JP. (2000). Textbook of Contact Dermatitis. Ed 2nd. Springer-Verlag Berlin Heidelberg. 